\title{
Early maximum growth of stony corals (Scleractinia) after settlement on artificial substrata on a Caribbean reef
}

\author{
Godfried W. N. M. van Moorsel* \\ Caribbean Marine Biological Institute (Carmabi), PO Box 2090, Curaçao, Netherlands Antilles
}

\begin{abstract}
This study reports maximum linear extension rates of several species of stony corals (Scleractinia) during formation of the colony base. Growth was determined during the first years after settlement of larvae on artificial substrata. Diameters of juveniles at the start of growth intervals ranged from 1.4 to $28.2 \mathrm{~mm}$; in $66 \%$ of measurements they were $<10 \mathrm{~mm}$. Substrata were deployed in different orientations between 5 and $30 \mathrm{~m}$ depth and thus offered a large range of environmental circumstances to demonstrate potential growth. A total of 769 growth values $\geq 0.6 \mathrm{~mm} \mathrm{mo}^{-1}$ diameter extension rate was measured in juveniles of 13 species. In 8 species sufficient data were collected to estimate maximum growth rates. Maximum diameter extension rates of about 2.1 to $2.4 \mathrm{~mm} \mathrm{mo}^{-1}$ were found in 1 ahermatypic species and in 6 hermatypic species. Acropora sp. was one of the latter species, which is remarkable in view of its relatively high adult growth rate. A range of 2.1 to $2.4 \mathrm{~mm} \mathrm{mo}^{-1}$ points to much slower juvenile growth rates than previously assumed, but is not much different from the scarce growth data available in the literature. The ahermatypic species Madracis pharensis forma pharensis showed a maximum diameter extension rate of $11.6 \mathrm{~mm} \mathrm{mo}^{-1}$. This rate is comparable to the most rapid linear extension rates ever recorded in hermatypic corals. It demonstrates for the first time that such fast linear skeletal extension rates are possible in the absence of zooxanthellae, not only on the actual growth site, but also in other colony regions. This finding constitutes an enigma, considering contemporary knowledge of calcification mechanisms and coral growth.
\end{abstract}

\section{INTRODUCTION}

After settlement a juvenile scleractinian coral occupies the surrounding substratum through expansion of its perimeter, which results in a base for the adult colony, This is a fundamental process, no matter whether the growth form of the adult colony is massive, branched, plate-like etc. Growth rates, or more specifically linear extension rates, of skeletons of juveniles play a paramount role in the dynamics of substratum coverage and the onset of interactions. Another ecological aspect of the growth of the coral colony base is its intimate relation to early survival: as soon as a certain critical size is reached, minor damage no longer implicates completely colony mortality. Such aspects indicate the relevance of the study of linear extension rates of juvenile coral skeletons.

\footnotetext{
- Present address: Netherlands Institute for Sea Research (NIOZ), PO Box 59, 1790 AB Den Burg, (Texel) The Netherlands
}

The initial growth of most species is predominantly parallel to the substratum. This encrusting or plate-like 2-dimensional growth form (Pearson 1981, Colgan 1987) permits meaningful inter-specific comparisons of juvenile extension rates.

Another reason to study juvenile growth is to gain insight into temporal aspects of settlement patterns: maximum extension rates of juveniles provide us with the minimal time span recruits must have been present between settlement and discovery.

Although extensive knowledge on growth of Scleractinia is available, most of it refers to large colonies. Data on juvenile growth can often be deduced only indirectly. Several methods have been used to estimate extension rates of juveniles. Underestimates can be deduced from recruits present on artificial substrata of known immersion time (Vaughan 1912, Rogers et al. 1984, Alino et al. 1985, Wallace 1985, Wallace et al. 1986), or on reef substrata that were intentionally (Hughes 1985) or unintentionally cleared (Rogers et al. 
1982). Real growth rates, however, can only be measured if several measurements on the same coral are made. On the natural reef, this has seldom been done (but see Bak \& Engel 1979, Rosesmyth 1984, Van Moorsel 1985), because it requires close scrutiny of the substratum to detect small juveniles. Some investigators have reared small corals from planulae in the laboratory and transferred them to the reef (Vaughan 1915, Babcock 1985, Sato 1985). Another possibility is to repeatedly measure corals settled on artificial substrata on the reef (Loya 1976a, 1985, Rylaarsdam 1983).

The latter approach was chosen for the present study. Artificial substrata with different orientations were deployed at several depths on the reef of Curaçao. Spatial and temporal aspects of coral settlement at these substrata will be reported elsewhere. Here, linear extension rates after discovery on the substrata will be presented for juveniles of 11 hermatypic and 2 ahermatypic species. For each of 8 species, 9 up to at least 379 growth values (diameter extension $\geq 0.6 \mathrm{~mm}$ $\mathrm{mo}^{-1}$ ) are available.

As is the case on natural substrata (Van Moorsel 1985), growth rates of colony bases are expected to be influenced by physical and biological disturbance (including competition). The significance of disturbance under artificial circumstances as a contribution to the understanding or reef ecology may, however, be questioned. Therefore, this study is not concerned with average growth, which may be a reflection of low or even negative growth values. Emphasis will be on maximum extension rates, which are presumed to represent undisturbed growth. Considering the wide array of environmental circumstances on the artificial substrata and the large number of growth values avalable, it is possible to give an inter-specific comparison of maximum linear extension rates of juvenile corals

\section{MATERIALS AND METHODS}

A set of artificial substrata was deployed on the reef of Curaçao (Netherlands Antilles) at each of 3 depths $(5,15,30 \mathrm{~m})$ on 1 or 2 February 1979 . The substrata had different orientations, horizontal and vertical. They are called 'grates' because they consist of cube cell material ('square honeycombs' of about $1 \mathrm{~cm}^{3}$ ). Cells were open on both sides (open grates) or closed on backsides (closed grates). A set of substrata and the substratum structure are shown in Fig. 1. Grate materials were smooth polystyrene for the cube cells and formica for the backwalls (in closed grates only). Settlement and growth, however, often took place on biogenic substrata that covered the grate materials (Van Moorsel unpubl.). For location see Van Moorsel (1985, Fig. 1); details on experimental set-up will be presented elsewhere.

At each of 7 SCUBA survey periods, I located newly settled corals in situ by scrutinizing the substrata, illuminating the cells with a small underwater lamp (Super Q, Underwater Kinetics). Positions were recorded by grate coordinates and a sketch of the grate cell. This enabled relocation of corals at successive surveys. Surveys were completed about $8.5,10.5,12$, $15,18,21$ and 25 mo after substratum deployment. For

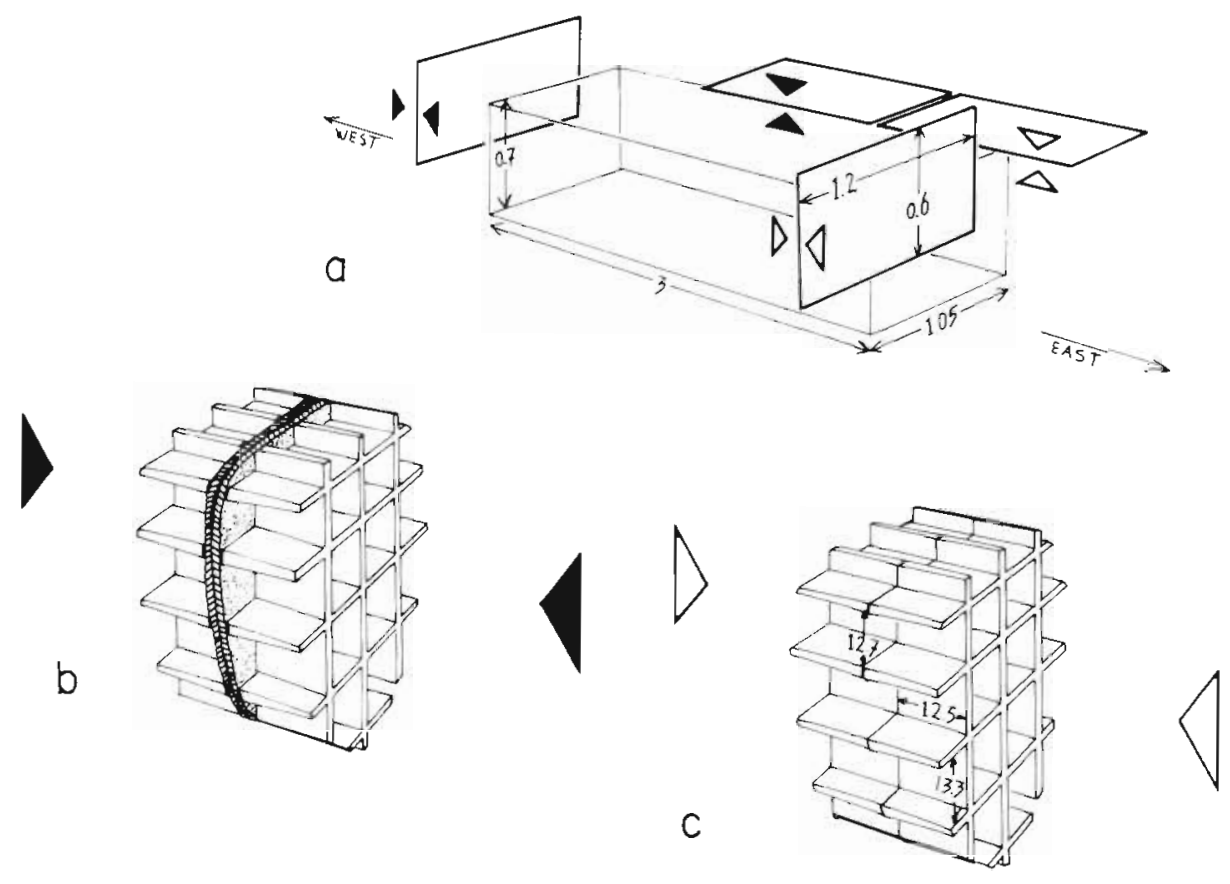

Fig. 1 (a) Set of 4 settlement substrata on frame (dimensions in $\mathrm{m}$ ). Triangles point to and symbolize horizontal and vertical grate sides. Open triangles: open grates; solid triangles: closed grates. (b) Detail of closed vertical grate. (c) Detail of open vertical grate (dimensions in $\mathrm{mm}$ ) 


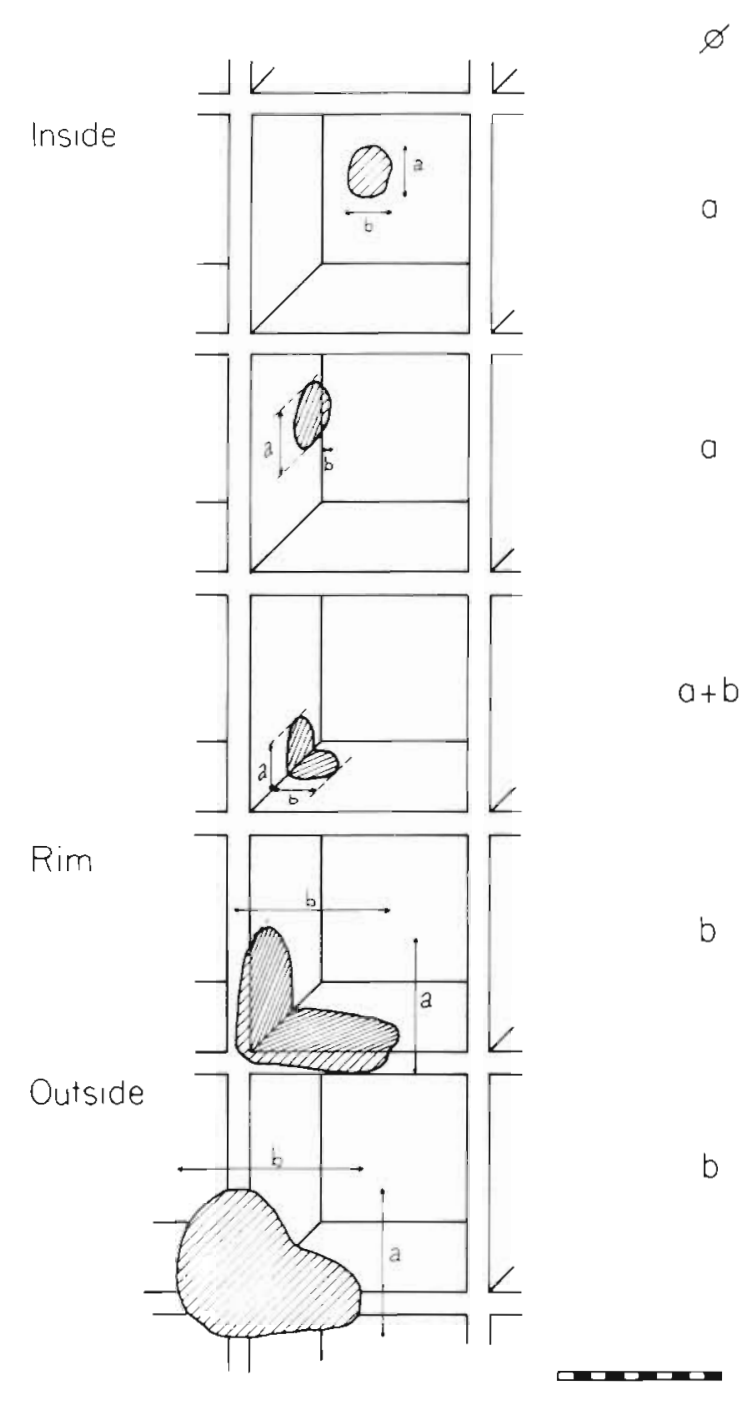

Fig. 2. Growth forms of corals (hatched) in respect to cell topography. a and b: size measurements. Diameter $(\varnothing)$ as determined from $a$ and/or $b$ is depicted on the right. Scale bar $1 \mathrm{~cm}$ with $1 \mathrm{~mm}$ divisions individual corals, intervals between surveys were at least $48 \mathrm{~d}$. Additional data were gathered after 49 mo. As a result of time limitations, this was done only on corals which had by then a diameter $\geq 30 \mathrm{~mm}$.

At each survey, coral sizes were measured and notes were made on coral location in relation to cell, viz. inside, rim and outside (Fig. 2). Size measurements were taken consistently along axes concomitant with cell edges, using a vernier calipers read to the nearest $0.1 \mathrm{~mm}$. Before measurement I tapped at the surrounding substratum, in order to measure skeletal dimensions (with retracted live tissue). Repetitive size measurements of the same corals showed a range of measurement variations of $0.5 \mathrm{~mm}$. The largest of 2 measurements was taken as coral diameter $(\varnothing)$. Only in corals growing inside cells, perpendicular measurements were added if this corresponded to colony diameter. In the latter cases variation of $\varnothing$ was $1.0 \mathrm{~mm}$ maximally. Fig. 2 supplies examples of growth forms of juveniles, measurements and diameter determination. In species mentioned in this study, 3738 diameter determinations were made.

Sometimes, diameters taken at successive surveys of the same coral were in fact normal to each other In these cases calculation of growth does not seem very realistic, but this procedure was preferred for reasons explained in 'Results'. Whether growth was considered to occur inside, outside, or at the rim of a cell of settlement, was determined by a similar designation of the location of the coral at the end of the growth interval. If growth was the result of a transition between 'inside' and 'rim' (cf. Fig. 2, 3th $\rightarrow 4$ th cell from top), the inside diameter was always taken as if this was a rim case, i.e. perpendicular measurements were not added.

In this paper, values of growth $(G)$ are expressed as monthly linear extension rates of coral diameter. $G=$ $30 \Delta \varnothing \Delta \mathrm{t}^{-1} \mathrm{~mm} \mathrm{mo}^{-1}$, in which $1 \%$ is diameter increase

Table 1. Average diameter ( $\bar{\nabla}$ in $\mathrm{mm}$, for definition see text) at start of growth intervals of juvenile corals with a $G$ of at least 0.6 $\mathrm{mm} \mathrm{mo}^{-1}$. To illustrate the distribution of diameter values, standard deviations (SD) and ranges of diameters are supplied. (A) Data from first 2 yr after deployment of substrata. (B) Data from 3rd and 4 th yr of substrata immersion. For number of diameters, and start diameters of species of which only 1 growth value was available, see Table 2

\begin{tabular}{|c|c|c|c|c|c|c|}
\hline \multirow{2}{*}{ Species } & \multicolumn{3}{|c|}{$A$} & \multicolumn{3}{|c|}{$B$} \\
\hline & $\bar{\varnothing}$ & $\mathrm{SD}$ & Range & $\bar{\varnothing}$ & $\mathrm{SD}$ & Range \\
\hline Acropora sp. & 5.8 & 2.4 & $3.3-11.0$ & 6.8 & 0.6 & $6.6-7.4$ \\
\hline Agaricia humilis & 9.3 & 3.9 & $1.9-27.3$ & 12.9 & 5.1 & $2.8-22.8$ \\
\hline Agaricia of humilis & 5.1 & 2.3 & $1.4-13.1$ & & & \\
\hline Agaricia agaricites & 11.2 & 4.9 & $3.8-20.1$ & 17.7 & 8.1 & $8.5-24.0$ \\
\hline Porites astreoides & 8.0 & 3.5 & $2.2-14.0$ & 10.9 & 6.0 & $5.3-19.9$ \\
\hline Porites porites & 9.0 & 3.4 & $3.3-16.3$ & 11.9 & 5.5 & $4.1-20.7$ \\
\hline Colpophyllia natans & 6.4 & 2.5 & $3.3-8.6$ & 11.9 & 4.9 & $4.8-15.4$ \\
\hline Madracis pharensis & 15.1 & 7.4 & $3.0-24.6$ & 28.2 & & \\
\hline Tubastrea coccinea & 7.8 & 4.7 & $1.8-21.8$ & 12.4 & 7.4 & $3.2-27.5$ \\
\hline
\end{tabular}




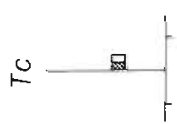

$\nabla$
$1+1+1+$
$\infty$

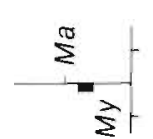

a - का

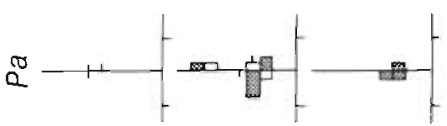
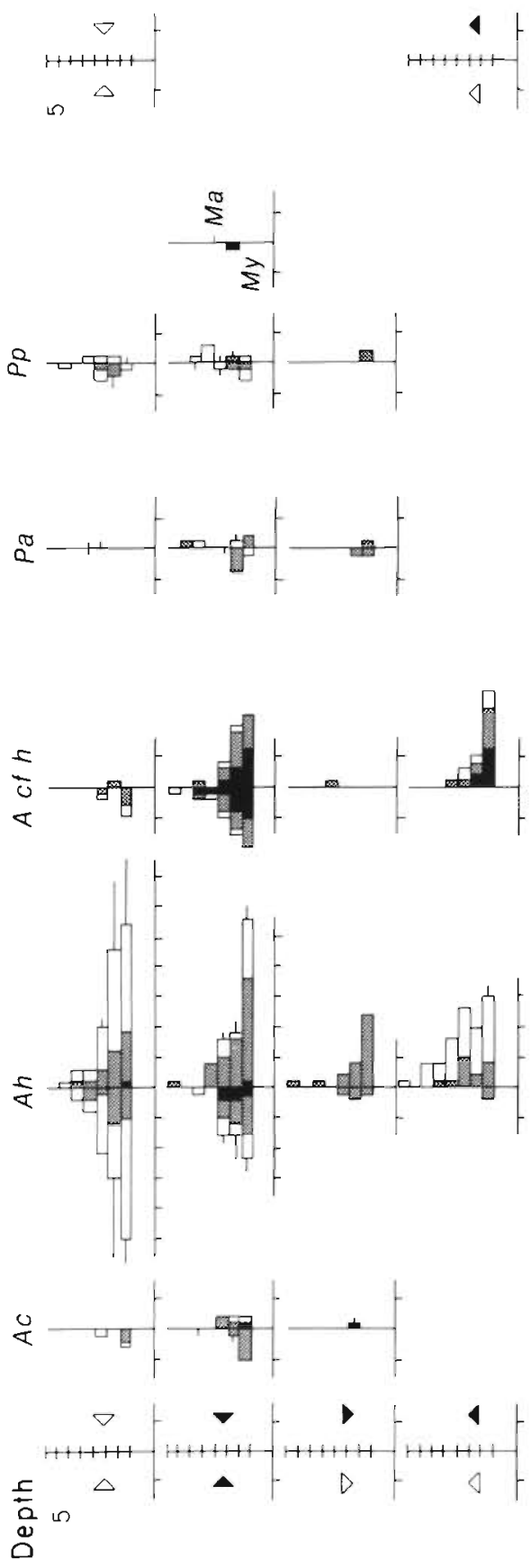
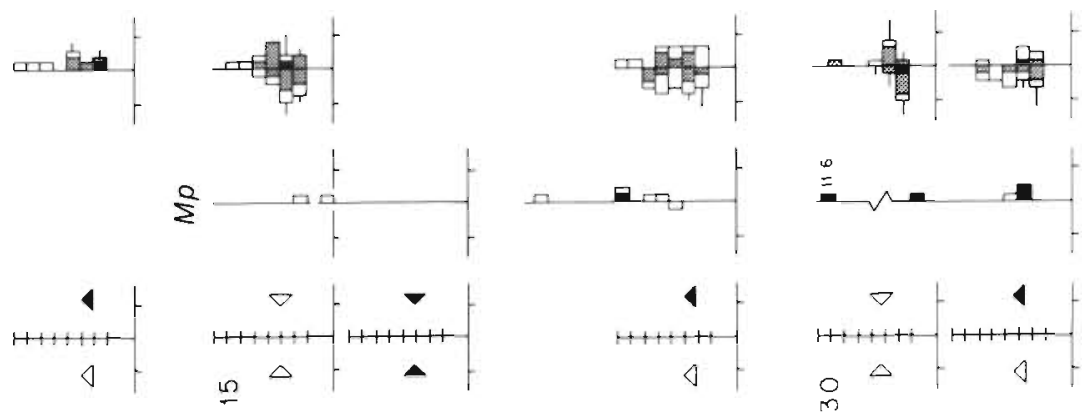

4
$4+++\infty$

$0 \Delta ; 0$
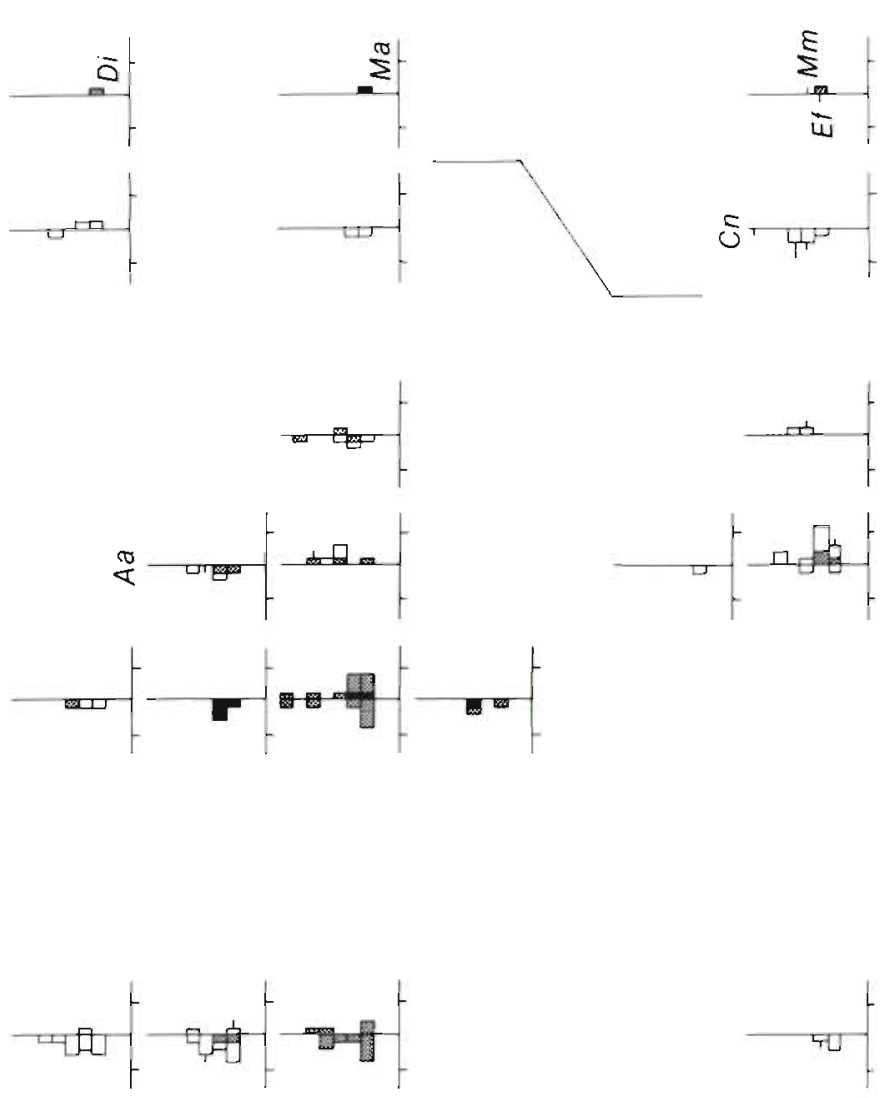

क ت

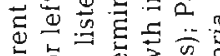

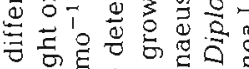

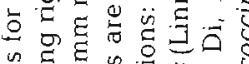

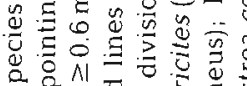

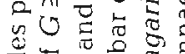

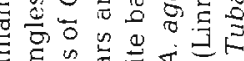

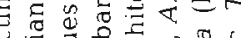

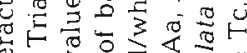

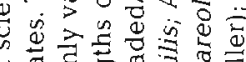

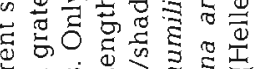

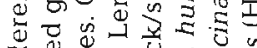

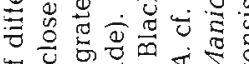

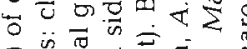

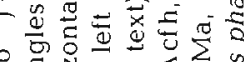

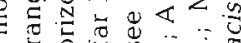

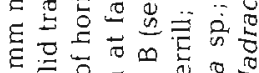

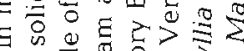

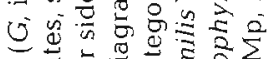

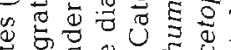

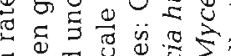

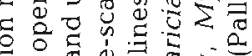

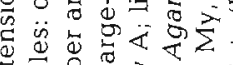

х

过过

हैं

응 $\varepsilon$ is

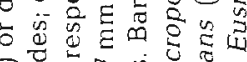

Q

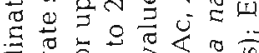

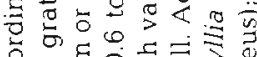

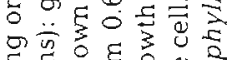

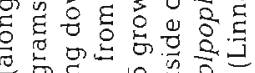

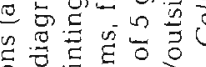

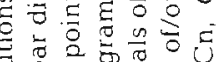

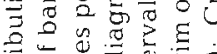

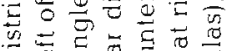

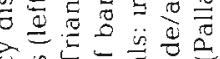

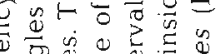

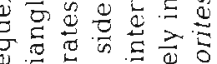

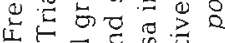

ल

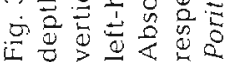


Table 2. Maximum diameter extension rates $(G)$ with diameter $(\varnothing)$ at start and end of growth interval ( $\Delta$ t). The 3 highest values (if available) per species per category (A and B) are listed. (A) Short $\Delta$ t during first $2 \mathrm{yr}$ after deployment of substrata; $\mathrm{cp}=\mathrm{cell}$ position ( $I, R$ and $O$, respectively inside, at rim and outside, see Fig. 2). (B) Long $\Delta t$ viz. 3rd and 4th year of substratum immersion, maximum bias always $\leq 0.04 \mathrm{~mm} \mathrm{mo}^{-1}, \mathrm{cp}$ always $\mathrm{O}$. $N$ : number of $G$ measurements $\geq 0.6 \mathrm{~mm} \mathrm{mo}^{-1}$. Grate designation: water depth $(5,15$ and $30 \mathrm{~m})$ and grate side symbols (triangles, see Fig. 1)

\begin{tabular}{|c|c|c|c|c|c|c|c|c|c|c|c|c|c|c|c|c|}
\hline \multirow[t]{3}{*}{ Species } & \multirow{3}{*}{$N$} & \multicolumn{8}{|c|}{ A } & \multicolumn{7}{|c|}{ B } \\
\hline & & \multicolumn{2}{|c|}{$\varnothing(\mathrm{mm})$} & \multirow{2}{*}{$\begin{array}{c}\Delta \emptyset \\
(\mathrm{mm})\end{array}$} & \multirow{2}{*}{$\begin{array}{l}\Delta t \\
\text { (d) }\end{array}$} & \multirow{2}{*}{$\begin{array}{c}G \\
(\mathrm{~mm} \\
\left.\mathrm{mo}^{-1}\right)\end{array}$} & \multirow{2}{*}{$\begin{array}{c}\text { Max. } \\
\text { bias } \\
(\mathrm{mm} \\
\left.\mathrm{mo}^{-1}\right)\end{array}$} & \multirow[t]{2}{*}{ Grate } & \multirow[t]{2}{*}{$\mathrm{cp}$} & \multirow[t]{2}{*}{$N$} & \multicolumn{2}{|c|}{$\varnothing(\mathrm{mm})$} & \multirow{2}{*}{$\begin{array}{c}\Delta \varnothing \\
(\mathrm{mm})\end{array}$} & \multirow{2}{*}{$\begin{array}{l}\Delta \mathrm{t} \\
\text { (d) }\end{array}$} & \multirow{2}{*}{$\begin{array}{c}G \\
\left(\mathrm{~mm}^{-1}\right)\end{array}$} & \multirow[t]{2}{*}{ Grate } \\
\hline & & start & end & & & & & & & & start & end & & & & \\
\hline \multicolumn{17}{|l|}{ Hermatypes } \\
\hline \multirow{3}{*}{ Acropora sp. } & 27 & 4.9 & 11.0 & 6.1 & 81 & 2.3 & 0.4 & $15>$ & $\mathrm{O}$ & 3 & 6.6 & $60^{d}$ & 53.4 & 772 & 2.1 & 5 \\
\hline & & 5.0 & 10.0 & 5.0 & 81 & 1.9 & 0.4 & $15>$ & $\mathrm{O}$ & & 6.3 & $34^{\mathrm{d}}$ & 27.2 & 745 & 1.1 & $5 \nabla$ \\
\hline & & 4.5 & 10.3 & 5.8 & 114 & 1.5 & 0.3 & 154 & $O$ & & 7.4 & 35 & 27.6 & 771 & 1.1 & 5 \\
\hline \multirow{3}{*}{$\begin{array}{l}\text { Agaricia } \\
\text { humilis }\end{array}$} & 322 & 19.8 & 27.3 & 7.5 & 81 & 2.8 & 0.4 & $5 \boldsymbol{\Delta}$ & 0 & 57 & 6.7 & 39 & 32.3 & 771 & 1.3 & $5-$ \\
\hline & & 4.2 & 11.1 & 6.9 & 80 & 2.6 & 0.4 & 54 & $\mathrm{R}$ & & 2.8 & 35 & 32.2 & 775 & 1.2 & $15 \downarrow$ \\
\hline & & 4.1 & 8.9 & 4.8 & 56 & 2.6 & 0.5 & $5 \nabla$ & $\mathrm{R}$ & & 16.5 & 48 & 31.5 & 762 & 1.2 & $5 \triangleleft$ \\
\hline \multirow{3}{*}{$\begin{array}{l}\text { Agaricia of } \\
\text { humilis }\end{array}$} & 117 & 4.0 & 9.1 & 5.1 & 61 & 2.5 & 0.5 & $5>$ & 0 & - & & & & & & \\
\hline & & 3.6 & 7.5 & 3.9 & 48 & 2.4 & 0.6 & $15 \nabla$ & $\mathrm{R}$ & & & & & & & \\
\hline & & 5.0 & 9.0 & 4.0 & 50 & 2.4 & 0.6 & $15 \nabla$ & $\mathrm{R}$ & & & & & & & \\
\hline \multirow{3}{*}{$\begin{array}{l}\text { Agaricia } \\
\text { agaricites }\end{array}$} & 25 & 8.4 & 11.5 & 3.1 & 48 & 1.9 & 0.6 & $15 \boldsymbol{\nabla}$ & $\mathrm{R}$ & 3 & 24.0 & 68 & 44.0 & 672 & 2.0 & $15 \nabla$ \\
\hline & & 7.9 & 12.5 & 4.6 & 76 & 1.8 & 0.4 & $30 \nabla$ & $\mathrm{O}$ & & 8.5 & 38 & 29.5 & 672 & 1.3 & 15 \\
\hline & & 16.9 & 22.0 & 5.1 & 85 & 1.8 & 0.4 & $30 \nabla$ & $O$ & & 20.6 & 39 & 18.4 & 672 & 0.8 & $30 \boldsymbol{\nabla}$ \\
\hline & 21 & 4.7 & 11.6 & 6.9 & 88 & 2.4 & 0.3 & 54 & $\mathrm{R}$ & 6 & 6.9 & 49 & 42.1 & 764 & 1.7 & $5 \triangleleft$ \\
\hline astreoides & & 7.5 & 11.2 & 3.7 & 50 & 2.2 & 0.6 & $15 \nabla$ & $\mathrm{R}$ & & 6.0 & 46 & 40.0 & 768 & 1.6 & $5 D$ \\
\hline & & 14.0 & 19.9 & 5.9 & 87 & 2.0 & 0.3 & 54 & 0 & & 16.1 & 54 & 37.9 & 771 & 1.5 & 5 \\
\hline Porites & 28 & 9.8 & 16.1 & 6.3 & 85 & 2.2 & 0.4 & $5 D$ & 0 & 7 & 4.1 & 51 & 46.9 & 772 & 1.8 & $5 \triangleright$ \\
\hline porites & & 10.9 & 16.3 & 5.4 & 86 & 1.9 & 0.3 & 54 & $\mathrm{O}$ & & 16.1 & 54 & 37.9 & 773 & 1.5 & 54 \\
\hline & & 7.3 & 11.8 & 4.5 & 78 & 1.7 & 0.4 & $15 \triangleright$ & 0 & & 8.3 & 44 & 35.7 & 771 & 1.4 & $5>$ \\
\hline Diploria sp. & 1 & 3.2 & 5.4 & 2.2 & 81 & 0.8 & 0.4 & $15 \triangleleft$ & $\mathrm{R}$ & - & & & & & & \\
\hline Manicina areolata & 1 & 5.8 & 8.2 & 2.4 & 84 & 0.9 & 0.4 & $15 \nabla$ & I & 1 & 6.4 & 46 & 39.6 & 777 & 1.5 & 54 \\
\hline Colpophyllia & 5 & 7.7 & 14.7 & 7.0 & 125 & 1.7 & 0.2 & $30 \nabla$ & $O$ & 4 & 14.7 & 82 & 67.3 & 752 & 2.7 & $30 \nabla$ \\
\hline natans & & 8.6 & 15.4 & 6.8 & 127 & 1.6 & 0.2 & $30 \nabla$ & 0 & & 12.5 & 56 & 43.5 & 749 & 1.7 & $30 \nabla$ \\
\hline & & 8.2 & 12.5 & 4.3 & 91 & 1.4 & 0.3 & $30 \nabla$ & 0 & & 4.8 & 48 & 43.2 & 750 & 1.7 & $30 \nabla$ \\
\hline $\begin{array}{l}\text { Meandrina } \\
\text { meandrites }\end{array}$ & 1 & 5.8 & 7.8 & 2.0 & 63 & 1.0 & 0.5 & $30 \nabla$ & $\mathrm{R}$ & 1 & 5.7 & 38 & 32.3 & 757 & 1.3 & $30 \boldsymbol{\nabla}$ \\
\hline Mycetophyllia sp. & 1 & 4.6 & 8.1 & 3.5 & 91 & 1.2 & 0.3 & $5 \triangleright$ & I & - & & & & & & \\
\hline Eusmilia fastigiata & & & & & & & & & & 1 & 10.6 & 33 & 22.4 & 749 & 0.9 & $30 \nabla$ \\
\hline Ahermatypes & & & & & & & & & & & & & & & & \\
\hline Madracis & 13 & 14.8 & 63.9 & 49.1 & 127 & 11.6 & 0.2 & $30 \boldsymbol{A}$ & I & 1 & 28.2 & 47 & 18.8 & 772 & 0.7 & 154 \\
\hline pharensis & & 10.3 & 24.3 & 14.0 & 95 & 4.4 & 0.3 & $15 \Delta$ & 0 & & & & & & & \\
\hline & & 21.0 & 35.6 & 14.6 & 132 & 3.3 & 0.2 & $30 \wedge$ & I & & & & & & & \\
\hline Tubastrea & 97 & 2.8 & 12.9 & 10.1 & 119 & 2.5 & 0.3 & $15 \Lambda$ & 0 & 26 & 5.0 & 39 & 34.0 & 737 & 1.4 & $5 \Delta$ \\
\hline coccinea & & 6.2 & 19.6 & 13.4 & 168 & 2.4 & 0.2 & $5 \Delta$ & 0 & & 5.9 & 37 & 31.1 & 770 & 1.2 & $30 \triangleright$ \\
\hline & & 5.3 & 10.9 & 5.6 & 74 & 2.3 & 0.4 & $30 \triangleleft$ & $\mathrm{R}$ & & 9.8 & 40 & 30.2 & 768 & 1.2 & $30 \triangleleft$ \\
\hline
\end{tabular}

in $\mathrm{mm}$ and $\Delta \mathrm{t}$ time interval in days. Because $\Delta \varnothing$ is derived from 2 measurements, maximum variation of $\Delta \varnothing$ is $2 \times 0.5=1 \mathrm{~mm}$. Maximum bias in $G$ is therefore $30 \Delta \mathrm{t}^{-1} \mathrm{~mm} \mathrm{mo}^{-1}$. Since $\Delta \mathrm{t}$ is at least $50 \mathrm{~d}$, variation of $G$ is at most $0.6 \mathrm{~mm}$ on a monthly basis, or twice this maximum if diameters are based on addition of 2 per- pendicular measurements. In longer intervals $G$ is more accurate. For example, the maximum bias was only 0.03 to $0.04 \mathrm{~mm} \mathrm{mo}^{-1}$ for values from the $2 \mathrm{yr}$ interval at the end of the study period. Values of $G<0.6 \mathrm{~mm} \mathrm{mo}^{-1}$ are less than the maximum range of variation of growth data. Probably, they all represent corals in which the 
growth process was disturbed. To obtain an indication of maximum growth, only $G$ values $\geq 0.6 \mathrm{~mm} \mathrm{mo}^{-1}$ suffice.

Two categories of $G$ data will be presented: (A) Data on corals less than 1.5 yr old. Diameters of these corals were measured mostly at about 3 mo intervals between 8 and 25 mo after substratum deployment. (B) Data on corals 2 to 3.5 yr old. They were measured 25 mo after deployment of the substrata and again 2 yr later. By then they had reached a diameter of $\geq 30 \mathrm{~mm}$. The diameter extension rate of these corals must have been at least $0.6 \mathrm{~mm} \mathrm{mo}^{-1}$. For coral diameters at the start of the growth intervals see Table 1.

\section{RESULTS}

Growth of the minor diameter was frequently higher than growth of the larger diameter. Such growth rates present an interesting phenomenon, because the results is a tendency to restore the symmetry of the coral (Stephenson \& Stephenson 1933, Loya 1976b, Van Moorsel 1985). Minor diameter growth was not used to determine maximum growth, because this growth is only important as long as the diameter in question is smaller than the longer diameter. Regenerative tissue growth, over previously killed parts of the colony, resulted in growth which was often higher than normal growth of tissue and skeleton. These observations were also excluded from the data set.

In Fig. 3, all growth values $\geq 0.6 \mathrm{~mm} \mathrm{mo}^{-1}$ are expressed as frequency distributions per species per grate side. The number of $G$ values per substratum (n) depends on the number of settlers (Van Moorsel unpubl.) and on the number of available growth intervals per coral. The distributions show that only a small part of the data can be considered to approximate maximum $G$. Allowing for different values of $n$, not much variation is seen in maximum growth rates on different substrata and at the 3 depths. On the contrary, the similarity is remarkable.

On the scale of the micro-habitat, hermatypic juveniles located at a cell's inside showed generally low growth rates. Of the growth values in Category A (see 'Materials and Methods' and legend of Table 2) derived from hermatypic juveniles located outside cells and at rims, respectively 19 and $12 \%$ had a $G$ in excess of $1.5 \mathrm{~mm} \mathrm{mo} \mathrm{m}^{-1}$. In juveniles inside cells this percentage was only $4 \%$. This difference was significant: $p<0.01$, test of independence (Sokal \& Rohlf 1981).

Table 2 lists details on the 3 highest $G$ values per species. For Category A it gives maximum bias, and for both Categories $\mathrm{A}$ and $\mathrm{B}$ it lists the number of growth measurements $\geq 0.6 \mathrm{~mm} \mathrm{mo}^{-1}(N)$, available of each species. If $N$ is large, the $G$ values probably include a maximum growth rate, which is at the same time probably biased on the high side. A small $N$ points to the possibility that the maximum potential growth has not been determined, and it is less likely that the maximum bias has to be subtracted.

Among all species with $N_{\mathrm{A}+\mathrm{B}} \geq 27$, there is a remarkable homogeneity in maximum $G$ of juveniles. This maximum diameter extension rate of about 2.1 to $2.4 \mathrm{~mm} \mathrm{mo}^{-1}$ has been found in the hermatypic species Acropora sp., Agaricia humilis, A. cf. humilis, A. agaricites, Porites astreoides, P. porites, and the ahermatypic Tubastrea coccinea. In Colpophyllia natans $(N=9)$ a slightly larger maximum of $2.7 \mathrm{~mm} \mathrm{mo}^{-1}$ was found.

In Category $B$, a small $N$ and/or large chance of growth disturbance during the whole 2 yr interval were probably responsible for a relatively low maximum $G$ in Agaricia humilis, both Porites species and Tubastrea coccinea. Despite the low number of measurements, a maximum $G$ equal to or even higher than in Category $\mathrm{A}$ was found in $A$. agaricites and Colpophyllia natans. The latter species have a large chance of undisturbed growth as a result of their plate-like growth form, somewhat elevated above the substratum. On natural substrata relatively low annual growth in the encrusting $A$. humilis has been related to a high risk of disturbance, whereas the growth form of $A$. agaricites was probably responsible for a relatively high long-term growth rate (Van Moorsel 1985).

Madracis pharensis showed a maximum $G$ of $11.6 \mathrm{~mm} \mathrm{mo}^{-1}$. Other $G$ values of $M$. pharensis are also relatively high. I have additional data which indicate that these extension rates are not exceptional in $M$. pharensis. At the last 2 surveys ( 21 and $25 \mathrm{mo}$ ), many newly settled large colonies were discovered ( $\varnothing$ up to $59.4 \mathrm{~mm})$. New settlers in all other species had grown only to much smaller sizes ( $\varnothing<20 \mathrm{~mm}$ ) upon discovery (Van Moorsel unpubl.). Assuming that they were absent at the previous survey, in 15 of the $M$. pharensis juveniles the diameter extension rate $G$ must have been at least 6.0 to $8.6 \mathrm{~mm} \mathrm{mo}^{-1}$ before discovery. At the underside of the closed grate at $30 \mathrm{~m}, 2$ additional M. pharensis colonies had a $G$ of at least 10.0 and $13.3 \mathrm{~mm} \mathrm{mo}^{-1}$. The maxima of 11.6 and $13.3 \mathrm{~mm} \mathrm{mo}^{-1}$ were found in colonies without zooxanthellae ( $M$. pharensis forma pharensis). These specimens grew as thin plates, over parts of the 'backwall' of the grate where it did not touch the cube cell material.

\section{DISCUSSION}

According to Wallace (1985), it takes several months before newly settled corals are large enough to become visible to the naked eye. The experimental approach 
Table 3. Maximum diameter extension rates $(G)$ of small corals. A $\varnothing$ of $1 \mathrm{~mm}$ at settlement is assumed where only end data are available

\begin{tabular}{|c|c|c|c|c|c|c|}
\hline \multirow{2}{*}{ Species } & \multicolumn{2}{|c|}{$\varnothing(\mathrm{mm})$} & \multirow{2}{*}{$\underset{(\mathrm{mm})}{\Delta Q}$} & \multirow{2}{*}{$\Delta t$} & \multirow{2}{*}{$\begin{array}{c}G \\
\left(\mathrm{~mm} \mathrm{mo}^{1}\right)\end{array}$} & \multirow{2}{*}{ Source/Remarks } \\
\hline & start & end & & & & \\
\hline \multicolumn{7}{|l|}{ Caribbean } \\
\hline Acropora cervicornis & 20 & 50 & 30 & $15 \mathrm{mo}$ & 2.0 & Rylaarsdam (1983) (branched) \\
\hline Acropora & $32^{4}$ & $76^{4}$ & 44 & $610 \mathrm{~d}$ & $>2.2$ & $\begin{array}{l}\text { Rosesmyth (1984) (average, branch- } \\
\text { less basal disc, from Fig.) }\end{array}$ \\
\hline Agariciasp. & & 12 & & $<13 \mathrm{mo}$ & $>0.8$ & Rogers et al. (1982) \\
\hline A. agaricites & & 31 & & $<26 \mathrm{mo}$ & $>1.2$ & Rogers et al. (1984) \\
\hline A. agaricites & $<20$ & $<40$ & & $1 \mathrm{mo}$ & 2.3 & $\begin{array}{l}\text { Bak \& Engel (1979) } \\
\text { (incl. A. humilis) }\end{array}$ \\
\hline A. agâricites & 29 & 58 & 29 & $364 d$ & 2.3 & Van Moorsel (1985) \\
\hline A. humilis & 25 & 54 & 29 & $364 \mathrm{~d}$ & 2.4 & Van Moorsel (1985) \\
\hline A. fragilis (?) & & 15 & & $<2 \mathrm{yr}$ & $>0.6$ & Vaughan (1912) \\
\hline Agariciids & & & 9 & $9-10 \mathrm{mo}$ & 0.9 & Rylaarsdam (1983) \\
\hline Porites astreoides & 12.3 & $\begin{array}{l}35 \\
19\end{array}$ & 23 & $\begin{array}{l}1 \mathrm{yr} \\
1 \mathrm{yr}\end{array}$ & $\begin{array}{l}1.9 \\
1.5\end{array}$ & $\begin{array}{l}\text { Vaughan (1915) } \\
\text { Vaughan (1912) }\end{array}$ \\
\hline Porites porites & & 16 & & $<2 y r$ & $>0.6$ & $\begin{array}{l}\text { Vaughan (1912) } \\
\text { (as P. clavaria) }\end{array}$ \\
\hline Pontuids & & & 13 & $9-10 \mathrm{mo}$ & 1.4 & Rylaarsdam (1983) \\
\hline Favia fragum & 11 & $\begin{array}{l}27 \\
20.5\end{array}$ & 16 & $\begin{aligned} & 1 \text { yr } \\
< & 1 \text { yr }\end{aligned}$ & 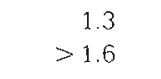 & $\begin{array}{l}\text { Vaughan (1915) } \\
\text { Vaughan (1912) }\end{array}$ \\
\hline Manicina areolata & $\begin{array}{r}9 \\
32\end{array}$ & $\begin{array}{l}21 \\
51\end{array}$ & $\begin{array}{l}12 \\
19\end{array}$ & $\begin{array}{l}372 \mathrm{~d} \\
372 \mathrm{~d}\end{array}$ & $\begin{array}{l}1.0 \\
1.5\end{array}$ & $\begin{array}{l}\text { Vaughan (1915) } \\
\text { (as Meandra areolata) }\end{array}$ \\
\hline Eusmilia fastigiata & & 22 & & $<2 \mathrm{yr}$ & $>0.9$ & $\begin{array}{l}\text { Vaughan (1912) } \\
\text { (as E. knorn) }\end{array}$ \\
\hline 'Recruits' & & 43 & & $<3.25 \mathrm{yr}$ & $>1.1$ & Birkeland (1977) \\
\hline $\begin{array}{l}\text { Pacific/Red Sea } \\
\text { Pocillopora damiconis }\end{array}$ & $8^{\mathrm{a}}$ & $20^{d}$ & 12 & $8 \mathrm{mo}$ & 1.5 & $\begin{array}{l}\text { Sakai \& Yamazato (1984) } \\
\text { (Fig. 5) }\end{array}$ \\
\hline P. damicornis & 2.5 & 7.5 & 5 & $17 \mathrm{wk}$ & 1.3 & $\begin{array}{l}\text { Sato (1985) } \\
\text { (branches at } \varnothing 3 \mathrm{~mm} \text { ) }\end{array}$ \\
\hline Pocillopora & & 38.2 & & $<22$ mo & $>1.7$ & Alino et al. (1985) \\
\hline Stylophora pistillata & & $\begin{array}{l}30 \\
40\end{array}$ & & $\begin{array}{l}15 \mathrm{mo} \\
22 \mathrm{mo}\end{array}$ & $\begin{array}{l}1.9 \\
1.8\end{array}$ & $\begin{array}{l}\text { Loya }(1985) \\
\text { Loya }(1985)\end{array}$ \\
\hline Acropora millepora & & 8.8 & & $5.6 \mathrm{mo}$ & 1.4 & Babcock (1985) \\
\hline Porites & & 24 & & $<22 \mathrm{mo}$ & $>1.0$ & Alino et al. (1985) \\
\hline 'Recruits' & 3.8 & $\begin{array}{r}5.2 \\
4.0 \\
3.8 \\
16.0\end{array}$ & & $\begin{array}{r}<8 \mathrm{mo} \\
<4 \mathrm{mo} \\
<4 \mathrm{mo} \\
1 \mathrm{yr}\end{array}$ & $\begin{array}{r}>0.5 \\
>0.8 \\
>0.7 \\
\\
1.0\end{array}$ & $\begin{array}{l}\text { Wallace \& Bull (1982) } \\
\text { Wallace (1985) } \\
\text { Wallace et al. (1986) } \\
\text { Wallace et al. (1986) }\end{array}$ \\
\hline
\end{tabular}

made it possible, however, to determine growth rates of corals with a diameter down to $1.4 \mathrm{~mm}$ (Table 1 ). Growth of naturally settled corals of this size has seldom been reported before.

Table 3 compiles the literature data on maximum diameter extension rates of juveniles forming a colony base. Growth of 2.3 and $2.4 \mathrm{~mm} \mathrm{mo}^{-1}$ was found in Agaricia agaricites and $A$. humilis in natural habitats (Van Moorsel 1985). This indicates that data from the artificial substrata are representative. Values published for other species are somewhat lower, but they are often based on small numbers (e.g. Vaughan 1912, 
1915), or they represent underestimates. Maximum $G$ in juveniles of most hermatypic corals lies within a range of 1.5 to $2.4 \mathrm{~mm} \mathrm{mo}^{-1}$. The fact that most species expand initially in the same 2-dimensional way over the substratum to form a colony base apparently does not permit much interspecific variation in extension rates. The only exception can be found in Madracis pharensis (this study, see below).

Up to the last decade, a consensus had prevailed that growth in juveniles was faster than in aduit colonies. Such a consensus cannot be maintained (Van Moorsel 1985). The statement of Connell (1973, p. 211) in Heron Island most corals can grow to a diameter of over $1 \mathrm{~cm}$ in about $1 \mathrm{mo}^{\prime}$ has also been debated recently by Babcock (1985), Harriot (1985) and Wallace (1985). The data presented in this study show that such a size cannot be reached until 4 mo after settlement. If only mean growth rates are considered, it more likely takes at least 1 yr to reach $1 \mathrm{~cm}$ diameter.

In large colonies of several branched and plate-forming coral species, the zones of the most rapid skeletal extension are free of zooxanthellae (Bak 1976, Oliver 1984). Examples are the Caribbean Acropora species, known to be extremely rapidly growing corals, with linear extension rates 5 to 10 times those in other species. The absence of symbiotic algae in these zones of rapid growth may be caused by regulation of zooxanthellar density by the host, or by a tissue conformation physically incapable to host algal cells (Oliver 1984). In a functional approach it has been suggested that zooxanthellae inhibit calcification if present at the site of fast extension (Bak 1976). Before the fast growing white-tipped branches of Acropora sp. develop, the coral passes through the 2-dimensional growth phase of the colony base reported in this study. The periphery of this colony base is not free of zooxanthellae and the growth rate of Acropora sp. is comparable to that of other species with plate-like growth. It is noteworthy that polyp density of the 2-dimensional colony base is much higher than in adult colonies and that the corallites do not emerge above the coenosteum like the tube-like corallites of adult colonies.

In the ahermatypic Tubastrea coccinea, maximum $G$ was as high as in hermatypic juveniles. In Madracis pharensis forma pharensis, the other species without zooxanthellae, a $G$ of 11.6 or even $\geq 13.3 \mathrm{~mm} \mathrm{mo}^{-1}$ has been found. These rates are comparable to the fastest linear extension rates ever recorded in zooxanthellaecontaining corals, viz. a branch extension rate in Acropora formosa (Dana) of $16 \mathrm{~mm} \mathrm{mo}^{-1}$ (Oliver et al. 1983) and $>16.7 \mathrm{~mm} \mathrm{mo}^{-1}$ in A. cervicornis (Lamarck) (Tunnicliffe 1983). Fast linear extension has been related with the absence of zooxanthellae at the site of fast extension (see above), but one could still envisage translocation of metabolites from zooxanthellae-con- taining regions of the colony to be responsible for such rapid extension rates. This is the first observation to report fast extension rates in corals that appear to host no zooxanthellae at all.

Some specimens of Madracis pharensis forma pharensis transferred into the forma luciphila Wells by acquiring zooxanthellae during the study. It seems that such a sequence allows fast initial extension before zooxanthellae appear. Why does such a seemingly 'simple' strategy for rapid colony-base extension not occur in hermatypic corals in general? During rapid extension, $M$. pharensis forms extremely thin crusts, which do not seem significant in terms of $\mathrm{CaCO}_{3}$ production. It enables the species to expand quickly over available substratum. This characteristic was demonstrated by $M$. pharensis colonies that occupied the whole surface of holes ( $\varnothing$ up to $14 \mathrm{~mm}$ ) in crustose coralline algae. These holes were caused shortly before by bites of parrotfish (own obs.). Possibly, growing as a thin crust over the substratum is a successful strategy only in the limited range of environments in which $M$. pharensis is found, i.e. in cryptic reef habitats such as the sheltered undersides of plate-like corals. On the open reef, species are more exposed to light, water movement and sedimentation. These circumstances may force corals to build a more massive skeleton, not only for early maintenance, but also because it forms a solid base for the colony that could arise from it eventually. It may be the role of zooxanthellae to provide this solidness by stimulating 'infilling' (Oliver et al. 1983). This aspect of calcification could be more important to characterize hermatypic coral growth than skeletal extension rates per se.

Acknowledgements. The Caribbean Marine Biological Institute (Carmabi), Curaçao provided research facilities. Help of Carmabi staff and dive buddies is gratefully acknowledged. The Netherlands Institute for Sea Research provided facilities for preparation of the manuscript. B. Verschuur (NIOZ) offered reprographic service. I thank Dr R. P. M. Bak for advice and comments on earlier versions of the manuscript. Professor Dr G. P. Baerends, R. Dekker, Dr F. C. van Duyl and Professor Dr J. J. Zijlstra also improved the manuscript. This investigation was supported by a grant from the Netherlands Foundation for the Advancement of Tropical Research (WOTRO) W84-167 to Dr R. P. M. Bak.

\section{LITERATURE CITED}

Alino, P. M. Viva Banzon, P., Yap, H. T., Gomez, E. D., Morales, J. T., Bayoneto, R. P. (1985). Recovery and recolonization on a damaged backreef area at Cangaluyan Island (Northern Philippines). Proc. 5th Int Coral Reef Congr. Tahiti (4), p. 279-284

Babcock, R. C. (1985). Growth and mortality in juvenile corals (Goniastrea, Platygyra and Acropora): the first year Proc. 5th Int. Coral Reef Congr Tahiti (4), p. 355-360 
Bak, R. P. M. (1976). The growth of coral colonies and the importance of crustose coralline algae and burrowing sponges in relation with carbonate accumulation. Neth. J. Sea Res. 10: 285-337

Bak, R. P. M. Engel, M. S. (1979). Distribution, abundance and survival of juvenile hermatypic corals (Scleractinia) and the importance of life history strategies in the parent coral community. Mar Biol. 54: 341-352

Birkeland. C. (1977). The importance of rate of biomass accumulation in early successional stages of benthic communities to the survival of coral recruits. Proc. 3rd Int. Coral Reef Symp. Miami (1), p. 15-21

Colgan, M. W (1987). Coral reef recovery on Guam (Micronesia) after catastrophic predation by Acanthaster planci. Ecology 68: 1592-1605

Connell, J. H. (1973). Population ecology of reef-building corals. In: Jones, O. A., Endean, R. (eds.) Biology and geology of coral reefs. Vol. 2 Biology I. Academic Press, New York, London, p. 205-245

Harriot, V. J. (1985). Recruitment patterns of scleractinian corals at Lizard Island, Great Barrier Reef. Proc. 5th Int. Coral Reef Congr Tahiti (4), p. 367-372

Hughes, T. P. (1985). Life histories and population dynamics of early successional corals. Proc. 5th Int. Coral Reef Congr Tahiti (4), p. 101-106

Loya, Y (1976a). Settlement, mortality and recruitment of a Red Sea scleractinian coral population. In: Mackie, G. O (ed.) Coelenterate ecology and behaviour. Plenum Press, New York, p. 89-100

Loya, Y. (1976b). Skeletal regeneration in a Red Sea scleractinian coral population. Nature, Lond. 261. 490-491

Loya, Y (1985). Seasonal changes in growth rate of a Red Sea coral population. Proc. 5th Int. Coral Reef Congr. Tahiti (6), p. $187-191$

Oliver, J. K. (1984). Intra-colony variation in the growth of Acropora formosa: extension rates and skeletal structure of white (zooxanthellae-free) and brown-tipped branches. Coral Reefs 3: 139-147

Olver, J. K., Chalker, B. E., Dunlap, W. C. (1983). Bathymetric adaptations of reef-building corals at Davies reef, Great Barrier reef, Australia. I. Long-term growth responses of Acropora formosa (Dana 1846). J. exp. mar. Biol. Ecol. 73: $11-35$

Pearson, R. G. (1981). Recovery and recolonization of coral reefs (review). Mar Ecol. Prog. Ser. 4: 105-122

Rogers, C. S., Fitz III, H. C., Gilnack, M., Beets, J., Hardin, J.
(1984). Scleractinian coral recruitment patterns at salt river submarine canyon St Croix USVI. Coral Reefs 3: 69-76

Rogers, C. S., Suchanek, T H., Pecora, F. A. (1982). Effects of hurricanes David and Frederic (1979) on shallow Acropora palmata reef communities: St Croix, U.S. Virgin Islands. Bull. mar Sci. 32: 532-548

Rosesmyth, M. C. (1984). Growth and survival of sexually produced Acropora recruits: a post-hurricane study at DisCovery Bay. Atl. Reef Comm. and Int. Soc. Reef Stud. Abstr. Miami, p. 105-106

Rylaarsdam, K. W. (1983). Life histories and abundance patterns of colonial corals in Jamaican reefs. Mar. Ecol. Prog. Ser. 13: 249-260

Sakai, K., Yamazato, K. (1984). Coral recruitment to artificial denuded natural substrates on an Okinawan reef flat. Galaxea 3: 57-69

Sato, M. (1985). Mortality and growth of juvenile coral Pocillopora damicornis (L.). Coral Reefs 4: 27-33

Sokal, R. R., Rohlf, F. J. (1981). Biometry, 2nd edn. W H Freeman and Co., San Francisco

Stephenson, T. A., Stephenson, A. (1933). Growth and asexual reproduction in corals. Scient. Rep. Gt Barrier Reef Exped 3: $167-217$

Tunnicliffe, $V$ (1983). Caribbean staghorn coral populations prehurricane Allen conditions in Discovery Bay, Jamaica. Bull. mar. Sci. 33: 132-151

Van Moorsel, G. W. N. M. (1985). Disturbance and growth of juvenile corals (Agaricia humilis and Agaricia agaricites, Scleractinia) in natural habitats on the reef of Curaçao. Mar. Ecol. Prog. Ser. 24: 99-112

Vaughan, T W (1912). The Madreporaria and marine bottom. deposits of southern Florida. Carnegie Inst. Wash. Yearbk 10: $147-156$

Vaughan, T W. (1915). Reef corals of the Bahamas and of southern Florida. Carnegie Inst. Wash. Yearbk 14: $220-231$

Wallace, C. C. (1985). Seasonal peaks and annual fluctuations in recruitment of juvenile scleractinian corals. Mar. Ecol. Prog. Ser. 21: 289-298

Wallace, C. C., Bull, G. D. (1982). Patterns of juvenile coral recruitment on a reef front during a spring-summer spawning period. Proc. 4th Int. Coral Reef Symp. Manila (2), p. 345-350

Wallace, C. C., Watt, A., Bull, G. D. (1986). Recruitment of juvenile corals onto coral tables preyed upon by Acanthaster planci. Mar. Ecol. Prog. Ser. 32: 299-306 